\title{
Estimation of the Different Parameters of Variation through Biometrical Approach in Pea (Pisum sativum L.)
}

\author{
Bijendra Kumar*, Meenakshi Rathi, Dattesh Tamatam and Hariom Suman
}

Department of Genetics and Plant Breeding, School of Agriculture, Lovely Professional

University, Phagwara (Punjab) 144411, India

*Corresponding author

\section{A B S T R A C T}

An experiment was conducted to get information on genetic variability, heritability and genetic advance in the twenty one genotypes including six parents and fifteen $F_{1}$ obtained

\section{Keywords}

Pea, Diallel mating, Variability, GCV, PCV, Heritability.

Article Info

Accepted:

17 October 2017

Available Online:

10 December 2017 through half diallel mating design in pea during 2016-17at the Research Farm, Department of Genetics and Plant Breeding, School of Agriculture, Lovely Professional University, Phagwara (Punjab). Quantitative analysis were carried out for all the characters which are directly or indirectly associated with the yield and yield contributing traits. Analysis of variance showed the significant variability for all the studied characters for parents and in $F_{1}$ significant variability observed in all the traits accept primary branches per plant and seeds per pod. High heritability was observed for all the characters accept primary branches per plant (37.68) which was less. Highest value of GCV and PCV were observed for pod density (10.76 and 11.80) which indicates the presence of high genetic variation. High heritability coupled with high genetic advance for the character days to maturity yield per plant and plant height which indicate the presence of additive gene action and used for future population improvement. The genotypes with specific characters can be utilized for hybridization programme.

\section{Introduction}

Pea (Pisum sativum L.) is an important legume grown as a garden and field crop throughout the temperate region of the world; it is also grown as a cool season crop. Botanically, pea belongs to the genus Pisum and species sativum, which is further divided into two cultivated varieties, hortenseand arvense. The garden pea, $P$. sativum L. $2 \mathrm{n}=2 \mathrm{x}=14$ ) comes under the variety hortense (Ambrose, 1995; Zohary and Hopf, 2000). It is an annual herbaceous crop of the family Fabaceae. According to Blixt (1970), the Mediterranean is the primary centre of diversity with secondary centre in Ethiopia.
Pea is the valued primarily for the nutritional quality having high protein as $20-30 \%$, vitamin A $-5 \%$, beta carotene $4 \%$, and sufficient carbohydrates. The growth and development of peas are determined by the interaction of genetic factors, the environment and agricultural practices (Acikgoz et al., 2009). India is the second largest producer of vegetables, next only to China, in the world with a production of 40 million tonnes from four million hectares of land area. In spite of that, this seemingly high level of production can provide only 208 grams of vegetables per capita (Sharma, 2003), as against the 
suggested dietary intake of $275 \mathrm{~g}$ and $250 \mathrm{~g}$ per capita per day for adult male and female, respectively for undertaking moderate work (Swaminathan, 2002).

Breeding for superior varieties requires selection of parents capable of transmitting their desirable characteristics and understanding of genetic variation for yield and yield associated traits. Therefore present investigation carried out to get knowledge about genetic variation, gene action, heritability and genotypic and phenotypic variances for the different quantitative traits.

\section{Materials and Methods}

Six genotypes of pea including Jyoti, Rachana, Pearpolo-5, KSP-2, PB-01 and AP3 were carried out at the Experimental Research Farm of School of Agriculture, Lovely Professional University, Phagwara, Punjab during Rabi season 2016-17. The experiment was conducted in diallel (Half diallel) mating design. Seeds of $F_{1}$ hybrids and parental lines were sown in a randomized block design with three replications on 12 November 2016. Each plot consisted of $15 \mathrm{~F}_{1}$ and 6 parent plants on three $1.5 \mathrm{~m}$ apart and $50 \mathrm{~cm}$ rows. Plant spacing was $10 \mathrm{~cm}$.

The soil of experimental site is sandy loam. Geographically, Punjab is situated at $31^{0} .15 \mathrm{~N}$ latitude and $75^{\circ} .42 \mathrm{E}$ longitude in North Gangetic plain in eastern part of Punjab (India). The temperature ranges between 22 and $46{ }^{\circ} \mathrm{C}$ in the summers. Winters in Punjab experience very large diurnal variations with warm days and downright cold nights. The average annual rainfall is $1100 \mathrm{~mm}$ (44 inch). Quantitative data were collected on five plants in each plot. Days to $75 \%$ flowering plant height $(\mathrm{cm})$, number of primary branches, pods/plant, pod length $(\mathrm{cm})$, pod density $(\mathrm{cm})$, number of seeds per pod, days to maturity, 100-seed and yield/plant were recorded. Regarding the statistical analysis data recorded on parents and the $F_{1}$ hybrids were analyzed together as suggested by Singh and Chaudhary (1979). The analysis of variance was done as suggested by Panse and Sukhatme (19780. The genotypic and phenotypic coefficients of variation were worked out according to the given by Robinson et al., (1949). Heritability in broad sense and expected genetic advance on the basis of percent of mean were worked out according to the method advocated by Burton and Devane (1953) and Johnson et al., (1955), respectively.

\section{Results and Discussion}

The mean sum of square in ANOVA revealed high variability among 26 genotypes for all the characters (except the number of primary branches per plant) at 5\% and $1 \%$ level of probability (Table 1). The highly significant differences might be endorsed to their genetic makeup of germplasm lines and various regions from where they have been collected. These results also confirmed by Jaiswal et al., (2015) and Gowher et al., (2013).

The mean performance of various genotypes has also showed good range of variability for various characters which were studied in present investigation (Table 2). The range recorded for days to $75 \%$ flowering $(67.33-$ $78.00)$, plant height $(68.03-83.10)$, primary branches per plant $(3.16-4.50)$, pod length (6.36 - 8.66), seeds per pod (7.43 - 9.06), pod density $(0.77-1.09)$, pods per plants (47.66 - 57.97), days to maturity (98.23 93.33), yield per plant (70.96 - 82.03), and 100 -seeds weight $(\mathrm{g})(11.10-15.03)$. These results also confirmed by Saleem et al., (2008).

The genotypic coefficient of variation, phenotypic coefficient of variation, heritability genetic advance and genetic 
advance as percent of mean also are present in Table 2. Based on investigation it was observed that phenotypic coefficient of variation was higher than the genotypic coefficient of variation for all the characters under studied, which is an indicator of additive effect of the environment of the expression of characters. It is also observed that the low range between PCV and GCV so it reveals that these traits have low sensitivity to environmental effects and it is reducible. Similar finding were also reported by Katoch et al., (2016), Siddika et al., (2013), Kumar et al., (2013) and Ahmad et al., (2014).

Genotypic coefficient of variation (GCV) ranged from $3.12 \%$ to $10.76 \%$. Higher magnitude of GCV was observed by Pod density (10.76\%). Similar finding were also reported by Similar findings were also reported by Afreen et al., (2017), Katoch et al., (2016) and Kumar et al., (2013), Pal and Singh (2013), Tyagi and Srivastava (2002) and Singh and Mir (2005). Low amount of GCV reported by 100 - seed weight $(8.53 \%)$ followed by pod length $(8.04 \%)$, primary branches per plant $(6.71 \%)$, plant height $(5.64 \%)$, seeds per pod $(5.62 \%)$, yield per plant $(4.81 \%)$, pod per plant $(3.91 \%)$, days to maturity $(3.88 \%)$ and days to $75 \%$ flowering $(3.12 \%)$.

Similar finding was observed by Georgieva $e t$ al., (2016). A high value of GCA is an indication of high genetic variability among the genotypes and thus the scope for improvement of these characters through simple selection would be better. Phenotypic coefficient of variation (PCV) ranged from $11.80 \%$ to $3.82 \%$. Highest magnitude of PCV was recorded for the pod density $(11.80 \%)$ followed by primary branches per plant $(10.93 \%)$. Similar finding was observed by Katoch et al., (2016), Jaiswal et al., (2015) and Pal and Singh (2013). The low amount of PCV were recorded for 100- seed weight $(9.27 \%)$ followed by pod length $(8.96 \%)$, seeds per pod(6.42\%), plant height $(6.10 \%)$, yield per plant $(4.94 \%)$, pod per plant $(4.44 \%)$, days to maturity $(4.03 \%)$ and days to $75 \%$ flowering. Similar finding were also reported by Katoch et al., (2016), Siddika et al., (2013), Kumar et al., (2013) and Ahmad et al., (2014). GCV measures the amount of variation present in a particular character but it doesn't provide an idea about the proportion of heritable variation present in the total variation therefore, heritability estimates were calculated in the present study. In the present study heritability estimates were high for all the studied character as categorized (Low $<30 \%$; Moderate 30-60\%; high $>60 \%$ ) by Johnson et al., (1955).

The estimates of heritability (\%) in broad sense for 10 characters studied, which range from high to low $94.78 \%$ to $37.68 \%$ respectively. Out of ten characters nine characters observed for high heritability viz., yield per plant $(94.78 \%)$, days to maturity (92.58\%), plant height (85.69\%), 100-seed weight $(84.75 \%)$, pod density $(83.25 \%)$, pod length $(80.61 \%)$, pods per plant $(77.63 \%)$, seeds per pod $(76.64 \%)$, and days to $75 \%$ flowering $(66.51 \%)$. Similar results were noticed by Afreen et al., (2017), Georgieva et al., (2016), Jaiswal et al., (2015); Kumar et al., (2015); Ahmad et al., (2014); Habtamu and Million (2013); Kumar et al., (2015); Sharma et al., (2003) and Kumarai et al., (2008). Low heritability was recorded for primary branches per plant (37.68\%).

Improvement in the mean genotype value of selected plants over the parental population is known as genetic advance. Expected genetic advance (GA) was calculated by the method suggested by Johnson et al., (1955).The estimates of genetic advance for 10 characters studied, which range from $10.72 \%$ to $0.23 \%$ (Table 2). The GA is categorized as Range Category $>20 \%$ High; 10-20 \%; Moderate $<10$ $\%$ Low. 
Table.1 Analysis of variance for 10 characters in pea parents $+\mathrm{F}_{1}$

\begin{tabular}{|c|c|c|c|c|c|c|c|c|c|c|c|}
\hline $\begin{array}{ll}\text { Source } \\
\text { variation }\end{array}$ & d.f. & $\begin{array}{l}\text { Days to } \\
75 \% \\
\text { flowering }\end{array}$ & $\begin{array}{l}\text { Plant } \\
\text { Height }(\mathrm{cm})\end{array}$ & $\begin{array}{l}\text { Primary } \\
\text { branches/plant }\end{array}$ & $\begin{array}{l}\text { Pod } \\
\text { length }(\mathrm{cm})\end{array}$ & Seeds/pod & $\begin{array}{l}\text { Pod } \\
\text { density }\end{array}$ & Pods/plant & $\begin{array}{l}\text { Days to } \\
\text { maturity }\end{array}$ & Yield/plant & $\begin{array}{l}100- \\
\text { seed } \\
\text { weight }\end{array}$ \\
\hline Replication & 2 & 0.90 & 1.09 & 0.13 & 0.20 & $0.08 * *$ & 0.00 & 2.38 & 1.00 & 1.11 & 0.20 \\
\hline Treatment & 20 & $18.23 * *$ & $60.95 * *$ & $0.26^{* *}$ & $1.19 * *$ & $0.70^{* *}$ & $0.03 * *$ & $14.65 * *$ & $44.83^{* *}$ & $42.92 * *$ & $4.11 * *$ \\
\hline Parents & 5 & $40.72 * *$ & $106.43 * *$ & $0.64 * *$ & $2.58 * *$ & $0.29 * *$ & $0.4 * * *$ & $37.70 * *$ & $71.30 * *$ & $42.09 * *$ & $6.17 * *$ \\
\hline Hybrids & 14 & $11.45^{* *}$ & $47.58 * *$ & 0.14 & $0.78 * *$ & 0.90 & $0.02 * *$ & $7.46^{* * *}$ & $37.95 * *$ & $46.23 * *$ & $3.66^{* *}$ \\
\hline Parent $v s$ Hybrid & 1 & 0.83 & $20.75^{*}$ & 0.02 & 0.01 & 0.00 & 0.00 & 0.11 & $8.92 *$ & 0.69 & 0.06 \\
\hline Error & 40 & 2.62 & 3.21 & 0.09 & 0.08 & 0.06 & 0.00 & 1.28 & 1.16 & 0.77 & 0.23 \\
\hline
\end{tabular}

*Significant at $5 \%$ level; ** significant at $1 \%$ level

Table.2 Mean, range, coefficient of variation, (GCV and PCV)), heritability, genetic advance and genetic advance as percent of mean for 10 characters of six pea genotypes

\begin{tabular}{|c|c|c|c|c|c|c|c|c|}
\hline \multirow[t]{2}{*}{ Characters } & \multirow[t]{2}{*}{ Mean } & \multicolumn{2}{|c|}{ Range } & \multicolumn{2}{|c|}{$\begin{array}{l}\text { Coefficient of } \\
\text { variation }\end{array}$} & \multirow{2}{*}{$\begin{array}{c}\mathrm{h}^{2} \text { (b.s.) } \\
\%\end{array}$} & \multirow[t]{2}{*}{$\begin{array}{l}\text { Genetic } \\
\text { advance }\end{array}$} & \multirow[t]{2}{*}{$\begin{array}{c}\text { Genetic advance as } \\
\text { percent of mean }\end{array}$} \\
\hline & & Min. & Max. & GCV\% & PCV\% & & & \\
\hline $\begin{array}{l}\text { Days to } 75 \% \\
\text { flowering }\end{array}$ & 73.09 & 67.33 & 78.00 & 3.12 & 3.82 & 66.51 & 4.91 & 6.72 \\
\hline Plant Height $(\mathrm{cm})$ & 77.67 & 68.03 & 83.10 & 5.64 & 6.10 & 85.69 & 10.72 & 13.80 \\
\hline $\begin{array}{l}\text { Primary } \\
\text { branches/plant }\end{array}$ & 3.56 & 3.16 & 4.50 & 6.71 & 10.93 & 37.68 & 0.38 & 10.87 \\
\hline Pod density & 0.91 & 0.77 & 1.09 & 10.76 & 11.80 & 83.25 & 0.23 & 25.93 \\
\hline Pods/plant & 53.88 & 47.68 & 57.96 & 3.91 & 4.44 & 77.63 & 4.91 & 9.11 \\
\hline Days to maturity & 98.23 & 93.33 & 103.66 & 3.88 & 4.03 & 92.58 & 9.69 & 9.86 \\
\hline Yield/plant & 77.87 & 70.96 & 82.03 & 4.81 & 4.94 & 94.78 & 9.63 & 12.37 \\
\hline 100- seed weight & 13.32 & 11.10 & 15.03 & 8.53 & 9.27 & 84.75 & 2.76 & 20.75 \\
\hline
\end{tabular}


Moderate genetic advance were recorded for plant height $(10.72 \%)$ Low estimates of genetic advance were observed for days to maturity $(9.69 \%)$, yield per plant $(9.63 \%)$, days to $75 \%$ flowering and pods per plant (4.91\%), 100-seed weight $(2.76 \%)$, pod length $(1.43 \%)$, seeds per pod $(1.06 \%)$ and pod density $(0.23 \%)$.

High heritability coupled with high genetic advance observed for yield per plant and days to maturity suggesting there by that these traits could be considered as reliable indices for selection and higher responses of this trait could be expected from selection. Similar findings were also reported by Georgieva et al., (2016), Katoch et al., (2016) and Jaiswal et al., (2015). The genetic advance (as per cent per mean) varied from $6.72 \%$ to $25.95 \%$ (Table 2). The higher genetic advance (as per cent of mean)was recorded for pod density $(25.95 \%)$ followed by 100 -seed weight (20.75), whereas lower genetic advance (as per cent of mean) were recorded for pod length (19.07), plant height (13.80\%), seeds per pod (13.00\%), yield per plant $(12.37 \%)$, primary branches per plant $(10.87 \%)$, days to maturity $(9.96 \%)$, pods per plant $(9.11 \%)$ and days to $75 \%$ flowering $(6.72 \%)$. Similar findings were also reported by Guleria et al., (2009), Akhilesh et al., (2007) and Kalloo et al., (2005).

It has been observed that based on genetic analysis of six different genotypes of ten diverse characters of pea plant, high variability estimated for all the characters accept primary branches per plant. Mean range of variability observed for all the characters. High genotypic coefficient of variation as well as phenotypic coefficient of variation for pod density. Heritability was estimated for yield per plant and days to maturity. Genetic advance for plant height and genetic advance as per cent of mean for pod density.

\section{Acknowledgement}

We are extremely thanks to Department of Genetics and Plant Breeding, School of Agriculture, Lovely Professional University, Phagwara (Punjab) for valuable suggestions and assistance provided during the course of investigation

\section{References}

Acikgoz E., Ustun A., Gul I., Anlarsal E., Tekeli A.S., Nizam I., Avcioglu R., Geren H., Cakmakci S., Aydinoglu B., Yucel C., Avci M., Acar Z., Ayan I., Uzun A., Bilgili U., Sincik M., Yavuz M. (2009) Genotype x environment interaction and stability analysis for dry matter and seed yield in field pea (Pisum sativum L.). Spanish Journal of Agricultural Research, 7: 96-106.

Afreen, S, Singh, A.K., Moharana, D.P., Singh, V., Singh, P. and Singh, B. (2017). Genetic evaluation for yield and yield attributes in garden pea (Pisum sativum var. hortense L.) under North Indian gangetic plain conditions. Int. J. Curr.

Ahmad, H.B., Rauf, S., Rafiq, M., UllahMohsin, A. and Iqbal, A. (2014). Estimation of genetic variability in pea (Pisum sativum L.). J. Glb. Innov. Agric. Soc. Sci., 2(2): 62-64.

Akhilesh, S., Meenakshi, S., Ashwini, R. and Yudhvir, S. (2007). Genetic variability and association studies for green pod yield and component horticultural traits in garden pea under high hill dry temperate conditions. Indian. J. Hort., 64: 349-354.

Burton, G. W. and Devane, E. H. (1953). Estimating heritability in tall fescue (Festuca arundiancea) from replicated clonal material. Agron. J., 45: 478-481.

Georgieva, N., Ivelina, N., and Valentin, K. (2016). Evaluation of genetic 
divergence and heritability in pea (Pisum sativum L.). J. BioSci. Biotechnol, 5(1): 61-67.

Gowher, A. W., Bilal, A. M. and Shah, M. A. (2013). Evaluation of diversity in Pea (Pisum sativum L.) genotypes using agro-morphological characters and RAPD analysis. Int. J. Cur. Res. Rev., 5(10): $17-25$.

Guleria S., Chongtham, N. and Dua, S. (2009). Genetic variability, correlation and path analysis studies in pea (Pisum sativum L.). Crop Res., 38(1): 179-183.

Jaiswal, N.K., Gupta, A.K., Dewangan, H. G. and Lavanya, R. G. (2015).Genetic variability analysis in field pea (Pisum sativum L.). Inter. J. Sci. Res., 4(1): 2006-2007.

Johnson, H. W., Robinson, H. F. and Comstock, R. E. (1955). Estimates of genetic and environmental variability in soybean. Agron.J., 47(7): 314-318.

Kalloo, G., Rai, M., Singh, J., Verma, M., Kumar, R., Rai, G.K. and Vishwanath. (2005). Morphological and biochemical variability in pea (Pisum sativum L.). Veg. Sci., 32:19-23.

Katoch, V., Singh, P., Devi, M. B, Sharma, A., Sharma, G.D. and Sharma. J. K. (2016). Study of genetic variability, character association, path analysis and selection parameters for heterotic recombinant inbred lines of garden peas (Pisum sativum var. hortense L.) under mid-hill conditions of Himachal Pradesh, India. Leg. Res., 39(2): 163169.

Kumar, D., Malik, S., Singh, S. K. and Kumar, M. (2013). Genetic variability, heritability and genetic advance for seed yield and yield components in garden pea (Pisum sativum L.). Vegetos- An Inter. J. Plant. Res., 26(1): 182-184.

Kumar, R., Kumar, M., Dogra R. K. and Bharat N. K. (2015). Variability and character association studies in garden pea (Pisum sativum var. hortense L.) during winter season at mid hills of Himachal Pradesh. Leg. Res., 38(2): 164-168.

Kumarai, A., Kumar, M. and Kohli, U.K. (2008). Genetic parameters and character association in garden pea (Pisum sativum L.) cultivars. Veg. Sci., 35: 160-164.

Pal, A. K. and Singh, S. (2013). Assessment and genetic variability in garden pea (Pisum sativum L. var. hortense). Int. J. Agric. Sci., 9(1): 293-296.

Panse, V. G. and Sukhatme, P. V. (1978). Statistical Methods for Agricultural Workers. ICAR Publications, New Delhi, India, pp. 68-75.

Robinson HF, Comstock RE, Harvey PH. 1949. Estimates of heritability and the degree of dominance in corn. Agron. J. 41, 353-359.

Saleem, M., Arshad, M. and Ahsan, M. (2008). Genetic variability and interrelationship for grain yield and its various components in chickpea (Cicer arietinum L.). J. Agric. Res. 46:109116.

Sharma, A. K, Singh, S. P. and Sharma, M. K. (2003). Genetic variability, heritability and character association in pea (Pisum sativum L.). Crop Res., 26:135-139.

Sharma, A. K, Singh, S. P. and Sharma, M. K. (2003). Genetic variability, heritability and character association in pea (Pisum sativum L.). Crop Res., 26:135-139.

Siddika A., Islam, A. K. M. A., Rasul, M. G., Mian M. A. K. and Ahmed J. U. (2013). Genetic variability in advanced generations of vegetable pea (Pisum sativum L.). Inter. J. Plant. Breed, 7(2): 124-128.

Singh, A. K. and Mir, M. S. 2005. Genetic variability, heritability and genetic advance in pea (Pisum sativum L.). Envt. Eco., 23: 445 - 449.

Singh, R.K. and B.D. Chaudhary, 
1979.Biometrical Methods in Quantitative Genetic Analysis. Kalyani publishers, New Delhi.

Swaminathan, M.S., (2002) Food groups and balance diet: Recommended dietary allowances. In: Essentials of Food and Nutrition - an Advanced Textbook, Vol. 2. pp. 1-23. Bangalore: The Bangalore Printing and Publishing Co. Ltd.
Tyagi, M. K. and Srivastava, C. P. (2002). Genetic variability and correlation among yield and yield characters over two environments in pea. Indian. J. of Agric. Res., 36: 53-56.

Zohary, D. and Hopf, M., (2000). Domestication of Plants in the Old World (3rd edn), Oxford University Press: New York. 316p.

\section{How to cite this article:}

Bijendra Kumar, Meenakshi Rathi, Dattesh Tamatam and Hariom Suman. 2017. Estimation of the Different Parameters of Variation through Biometrical Approach in Pea (Pisum sativum L.). Int.J.Curr.Microbiol.App.Sci. 6(12): 2193-2199. doi: https://doi.org/10.20546/ijcmas.2017.612.251 